\section{SOME REMARKS ON PATHOLOGICAL SCHOOLS.}

By Edward S. Prior, M.A.,

ABCHITECT OF THE GAMBRIDGE UNIVERSITY NEW MEDICAL SCHOOLS.

A NEED has come for a fresh departure in the planning and construction of schools for special purposes. The architecture of such schools has long been at the mercy of the traditional idea that building is a compromise between the ornamental styles-that are considered those of art-and the building ways-that are considered those of modern construction. The fact is that the systematic training of architects has been almost entirely in the technicalities of bouse and church building. Architecture has been defined in the terms of such building, and the planning of schools has been evolved mostly as a hybrid-some cross or other between a mansion and a religious meeting-house. No doubt one class of school, that of the school board, has emancipated itself in some hands and has been built for its purpose. But even with this model how few are the private or public institutions for scientific education that show building individuality or such adaptation as declares specifically the object for which the building exists. Whether that be divinity, music, or shorthand, planning and construction usually have kept to a colourless unconsciousness. But even the school board model is not adapted for the more technical kinds of school building. The accommodations of these are not for classes taught orally but for students trained in laboratories (rightly called working rooms), by working in which scientific practice grows into the habit of the student's life. The medical school is, perhaps, the most special of such laboratory schools and has many needs which cannot be approached on the basis of ordinary architectural method. Its essentials of efficiency differ widely from those of a church, a mansion, or a public building. The canons, say, of the architectural competition as to planning would be hopelessly at fault in judging of the plan of a pathological school. And no less does the construction of such a school stand outside current building practice. Not only must it have special provisions for its economy but even a wholesale rejection of many timehonoured traditions of building. To some extent this is true of all medical building in which scientific sanitation is attempted, and it may be thought that the medical school comes under the heading of hospital architecture. But in practice the hospital model takes one but a little way. The ward system, with its lighting and ventilation, its isolations and publicities, the effective combination of which makes the hospital plan, has no counterpart in the necessities of a building which is essentially not a dormitory but a workshop; which is no caravansary for sojourners under observaticn but rather a group of cells for the training of neophytes, the hermits of science who may attain perfection.

I propose here to give some slight account of the steps which lead the planning and construction of the pathological school away from the traditions of ordinary building, and I deal first with construction because in it we have the foundation of planning which is conditioned by it to an extent that is sometimes not perceived. The fact is that houses and churches have so long been in the habit of life that the initial compromise as to their building and planning-that give and take between what could be built and what was wanted to be built-has left little remembrance of itself. But all forms of building art are based on such a compromise : and when new needs of convenience arise then a new review must be made of the facts of construction, and the terms of agreement between art and use rearranged thereon. It will be seen at once how the necessities of a medical school call for divergence from the builder's habit. Our English technique of building for some centuries has developed itself in a system of race work - the deliberate masking and draping of the lay figures of bare construction. The misfits have been taken quite unconcernedly-disregarded hollows have been allowed to multiply beneath the skin of style. But such get full of fluffy dust or worse ; they are the lairs of blackbeetles, spiders, rats, and mice, so that an old house is indeed a place of many mansions-a zoological museum with whole sets of uncatalogued specimens. Now a pathological or bacteriological school ought to be aware of what it propagates, lest by chance the cultures, the observation of which is its business, prove too successful and escape where they cannot be controlled. The medical building really cannot follow the older traditions; the signal is at danger and the art of building must be switched on to a new course in order to run with ordinary safety.

The essentials of construction for medical schools are : (1) perfect solidity of all the inclosing construction, so that no unfilled spaces are left in its walls, floors, or roofs ; (2) a smoothness of all the surfaces and the elimination of all crevices and ledges for dust; and (3) such a treatment for all corners and angles that they can be easily and thoroughly cleaned. How far this means a revolution of ordinary building modes will be understood by anyone who will look at an ordinary building in course of construction. ${ }^{1}$ For example, joisted floors are mostly but a series of catch-pits into which dust and dirt perpetually drift and which are quite uncleanable. Most of the patent concrete floors have hollowed spaces in their body and are open to the same objections. Then the whole tradition of wall ornament, of its skirtings, surbases, cornices, of its door architraves and window linings, fosters not only the numberless little zoological lairs which we have hinted at, but a system of elaborated dust ledges, such as spring cleanings never thoronghly clear. Moreover, the habit of cubic construction makes corners into which no cleaning implement can find its way; nests where without disturbance dirt colonies may live for generations.

Now it is possible to build without accepting the laws of all this tradition and (though it is not to my point here) the art and beanty of building need not suffer by their rejection. For though these cornices, architraves, \&c., are now the associations of architectural taste, yet it was strictly in the meeting of definite needs that these associations were created, and other needs can produce new associations of equivalent value. If we build for the direct object of cleanliness we shall create associations of taste. For the beauty of art seems to spring insensibly out of the simple expression of some direct need. It has certainly always been so in the building art. The simple necessity of vaulting in stone was an impetus to Gothic art, and vaultings of perfectly unadorned construction are beautiful. A clean unequivocable building for the purpose of defence was the Chatteau Gaillard and of it said Richard Coeur-de-Lion, "Is she not fair, my one-yea old ?" Certainly so far as the constructed shell of a building is concerned, there need be no concealed vacancies, no square angles, no projecting dust traps; doors and windows can be smoothly modelled and need have no architraves or other trappings of traditional architecture; skirtings and cornices can be part of the walls which they adorn inst ead of additions which only sham solidity; rounded modellings and shaped angles can give facility for cleansing. And the art of all such building need be none the worse-nay, rather the better-for its independent return to first principles and the rejection of the creeds of some outworn art. Finally, roofs (though this is the hardest task) can be such constructions of concrete and steel that the necessary spans are covered on the safe principles of smoothness and solidity, with no residuum of unventilated crannies, with no unsuspected catchpits and vantage-points for dust not even a rivet-head need project. There are adaptations of present day materials which can build all this without difficulty or expense ; the desire to do it has only to be urgent and the way is open. Again, the finishing of the rooms of a medical school can be approached on the same lines of construction being direct for the purpose. We can claim help from one or two simple devices-notably that of "bracket-bricks" or built-in iron blocks for the fixing of all supports, we can use forms of solid partitioning and certain patent slabs which can be made jointless. One principle, if steadily adhered to, will allow perfect cleanliness if it does not actually enforce it. It is this-that the level tops and all ledges or holes that are necessary should be where they are directly open to the eye; and secondly, where their cleaning can be thorough and systematic. All the furniture of a laboratory can be constructed and placed so that it is sealed from dust as to its interiors and so that its exteriors can be submitted to constant cleansing.

There are difficulties, no doubt, with the pipes-the light and water conductors-the wastes, taps, sinks, and shaftings of a laboratory. The wastes can be glazed channels in the floors, made to run straight to the outside of the building,

1 The extent to which what appears solid in building is really cellular is not generally understood Many walls are built purposely hollow and, with purpose or not, the trade bricklayer using as little
mortar as possible leaves the walls half air-space. 
with removeable covers so that their whole lengths can be constantly inspested and flushed. All pipes can be best managed by their being placed on the walls where they can be directly got at and where the least accumulation of dust and dirt about them can be detected. They should be painted white so that the dirt may be conspicuous and this provocation to cleanliness should be everywhere adopted, for it is fortunately supported technically by the fact that white paint is the only pure paint, all colouiring added thereto being a detrimental adulteration. The stair flights of public buildings as ordinarily constructed provide many little fastnesses for the dirt tribes from which no cleaning implement can drive them, but construction can minimise the deeply set angles where the treads abut on the walls and there is no necessity to add to medical staircases such accessories of style as dust-catching balustrades. The science of sanitary materials for wall surfaces has for some time received considerable attention in hospital construction and $I$ do not propose to enter on the discussion of specialities as to which rivalry exists. But one may point out as extraordinary that while there has been keen competition among the manufacturers of perfectly smooth non-absorbent substances in the way of glazed tiles, \&c., the pertinent facts as to the fixing of these tiles and ultimate history of their glazes have been disregarded. Most of the glassy wall coverings offered have the objection that, perfect in themselves, their joints cannot be made thorough, so that the attachment of them to the walls leaves crevices. And too often the most glassy surfaces carry in themselves the seeds of destruction. In fact, the higher the glaze the greater the tendency to scale, owing to the high tension and the uneven contractions of the surface and under material. The best success has been with the thick rougher glazes and coarser makes the jointings of which can be made thorough. no need to make them thick stone mullions and tran. soms, as under the belated traditions of style is often done as a sort of compromise between use and art For art's sake the top lights are glazed in little squares; while for use formless big sheets below advertise themselves as in obvious disagreement. Indeed, thick mullions and the heavy transom become particularly bad for the microscope that has to be used at a distance. The best lighting of a working laboratory for a class of students where tables have been ranged behind one another is that of the weaving shed, with north sloping skylights. But in order that the necessary bars of the skylight construction may not spoil the microscope field for work at the tables the height of the room must be as low as possible. The nearer the skylights are to the work the greater the unbroken spaces in the reflection. Such weaving-shed roofs require careful construction to be successfal. The ordinary steel building of roofs has had no thought of minimising to the utmost the ledges for dust and dirt.

It will be seen how immediately these essentials of lighting connect the constructive question with that of planning and arrangement. Where the aspect and construction of certain rooms are exactly indicated by the conditions of microscope use the available spaces must be mapped out accordingly. The plan must provide for the constructions necessary to this purpose and dispose the other parts of the building to suit. Besides the laboratories in which microscopes are in use the equipment of a medical school needs lecture theatres and oral class rooms. Now here, too, we come upon conditions which separate the building of the medical school from that of others. Under modern conditions of teaching by the projection lantern the use of artificial light in the medical lecture room is almost constantly required. Hence it is want of economy labor.

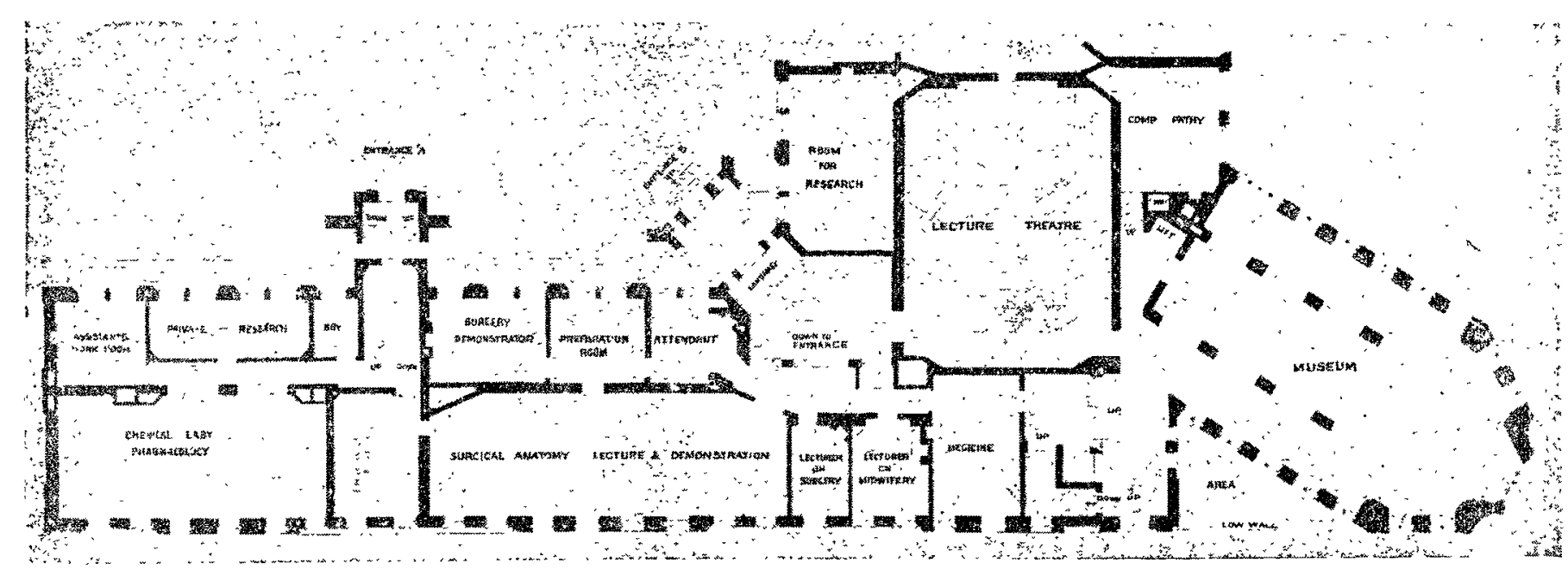

The ground floor of the Cambridge Medical Schools, showing the lecture theatre dependent entirely upon artificial light.

The sketch I have made above of what is possible in laboratory construction has to be supplemented in many particulars. Especially the controversial question of heating and ventilation has to be reckoned with, since decision on this point involves many constructional consequences. Particularly the mechanical appliances necessary for the shifting of the air and the fittings required to regulate its proper course throughout the rooms must be so applied that they do not create those dirt traps and that dust concealment which all the rest of construction has striven to minimise. The lighting of laboratories is also a special point in their architecture and one that is often shirked or considered as an afterthought instead of a consistent factor in the problem of their design. For most of their purposes north light is the only one that is satisfactory. East light is better than west, since the use will be more often in the afternoon, but south lighting should be used only for the less distinctive departments and offices of a medical school. But it is the make of the windows that needs specialising, seeing that their use is to light microscope practice. They have to be made convenient for two ranges of tables, one at the windows and the other back in the room. It has been found that at table. height and at a distance of ten feet (which is a convenient distance for the second range of microscopes) an unbroken oblong opening of glass 24 by 20 inches gives the proper field. The divisions to carry such sheets of glass need to be strong and so are best of iron. There is inusly to give what is not wanted for the lecture theatre an outlook upon open areas the wealth of daylight of which is of such importance elsewhere. Yet so strictly does architectural convention apply its canons that the building of a room without admission of daylight to it is reckoned a freak. For the pathological school this vagary is, however, not only to be sanctioned but made the direct way to success in planning economically and to the purpose of the building.

On all sides do the conventions which govern the planning of most public buildings fail us for the dispositions of a medical school. Access by means of broad corridors, the symmetrical approach to the rooms and the serried arrangement of them in sets are the qualities which show well in the paper planning of our public buildings and obtain their reward by success in competitions. But the medical school needs none of these and indeed must count all such stateli. ness as waste of space. The arrangements of workshops and factories, not those of public offices, are most convenient to it. It must cluster functional departments round the laboratories, giving immediate openings from room to room and providing a general inter-communication in which much corridor is inconvenient. In its lecture theatre and libraries and museums no donbt the ordinary arrangements for allowing easy approaches must be studied but with many differences from those in use for a less special institution.

As to its lecture theatre, a large preparation room should be immediately attached to the rostrum of the lecturer whose 
table should be in sight from all the benches and provided with special arrangements for lantern work. It is a useful point that the access corridors by which the stndents reach the theatre should be large enough to have cases set in them, so that the students passing in or out may supplement the lecture by personal study of specimens illustrating the sub. ject treated.

The library, just as the lecture theatre, should of course be centrally placed and easy of access. Seeing that the majority of books to be consulted by the medical student are special rather than general works, there need not be those facilities for reference to open shelves which general libraries develop to the full. The block system of stacking the books together, with bookcases that pull out into the room, should be used for such a library, since it gives central spaces for a student's table as well as allowing the bulky library of a medical school to be in a form in which it can be easily consulted. In the same way the medical museum is not quite on the lines of other museums, since its specimens have constantly to be brought into the lecture theatres and laboratories.

Another special department of the medical school is that which provides the rooms fcr private research. As already said, the scientific education does not lie in a few years' attendance at lectures but is the inducement to a mental habit to be exercised on constant experiment. The placing of the student where he can proceed with definite work is the necessary complement of his preliminary training. Now to equip all this experimont there are many special departments that a pathological laboratory must provide-rooms for cultivation, for sterilising, for distillation, for freezing, for cremation, as well as for photography, glass-blowing. \&c. All this bears out my initial definition, that the basis of the medical school planning lies in the idea of workshops or scientific factories. And in this connexion one necessary provision, that of sheds and stables where can be properly housed both the larger and smaller animals necessary for pathological experiment, can be seen to mean a very special contrivance in the planning.

[To give some distinctness to the variety of feature which the arrangement and equipment of a medical school involve Mr. Prior inclosed the plans of the Government laboratories at Netley which the War Office proposed to build for the Army Medical Service. The arrangements were planned under the direction of Professor A. E. Wright and Professor R. H. Firth but the buildings have never been put up. When the foundations bad been dug it was decided at headquarters that Netley was not the proper place for a medical school. Since there was a perfectly open site for this building the dispositions were unfettered and an order and symmetry could be adopted which the very confined site of the Cambridge Medical School did not allow. The latter, however, when completed, will deal with a much wider range of scientific requirements than the somewhat limited purpose of the medical school at Netley proposed. We therefore refer our readers to a fully illustrated article on Mr. Prior's new and highly successful medical schools at Cambridge, which were opered by His Majesty the King at the beginning of last month (see THE LANCET, Feb. 27th, pp. 599 et seq.). It will be seen by that article how closely Mr. Prior has adhered in practice to his tenets, and it will be admitted that his buildings have lost nothing æasthetically by his intention to subordinate every feature, whether of construction or ornament, to his aims of practical utility.ED. L.]

\section{THE ROYAL ACADEMY.}

THE one hundred and thirty-sixth exhibition of the Royal Academy of Arts, which will be open to the public on Monday next, contains many good and interesting pictures. There are others deserving neither qualification and it would be surprising if this were not the case, for the rooms at Burlington House contain nearly 2000 pictures, watercolours, drawings, miniatures, sculptures, and bronzes. On the whole, the level of achievement, we think, may be considered high, certainly higher than that attained by the other annual exhibitions. The hanging committee has had regard to modern developments in painting and the old Academicians have only sparingly availed themselves of their vested right to space, so that room has been found for a representative collection of works of art of which, as a non-artistic people, we need not be ashamed.

Of course, there are some dreadful presentation canvases, dall scenes or unlovely people in unbecoming costumes, whose features no painter's skill has been able to make into a pleasing show. But there are, on the other hand, some beautiful portraits, Mr. Sarjent and Mr. Shannon in particular carrying on the traditions of Reynolds and Gainsborough. Mr. Sarjent sends six large portraits, three of women-Lady Lathom, the Duchess of Sutherland, and Mrs. Wertheimer -and three of men-Lord Londonderry, Major-General Wood, and Mr. Devitt. Of these the women are the best. Not that they have necessarily had the most care bestowed upon them, for probably the portrait of Lord Londonderry in Coronation costume, bearing the sword of state and attended by his page, is the most elaborate of all. Nor have concessions been made to prettiness in the female portraits, for the Oountess of Lathom is represented with a markedly asymmetrical mouth, while her arms and hands do not strike us as being elegant factors in so stately and highbred a total. Still, it is impossible not to feel that the portrait is a lifelike though uncompromising representation of the sitter, and the same may be said of the somewhat smaller portrait of Mrs. Wertheimer. As in the case of Lady Lathom the colour scheme here is sombre, but the blacks and greys and yellowy browns make up a very pleasant picture. The Duchess of Sutherland, on the contrary, is painted in a glorious metallic green robe, contrasting vividly with her sunny hair. She has a high colour and a bright smile and is altogether a very satisfactory example of young and splendid womanhood. Mr. Shannon sends four portraits -Mr. Martin Harvey in his well-known representation of "Sydney Carton," Sir William Emmerson, the President of the Royal Institute of British Architects, Miss Gladys Raphael, and two young ladies, daughters of $\mathrm{Mr}$. W. H. Bell, painted together on a sofa. In this picture Mr. Shannon is particularly happy, the figures are restful, as figures on a sofa should be, the poses are natural, and painter and sitters are alike to be congratulated. Mr. William Orpen's portrait of Mr. Charles Werthemier is a very satisfactory performance. Mr. Arthur Hacker sends an admirable portrait of the Rev. E. S. Roberts, for many years tutor and now master of Gonville and Cains College, Cambridge, whose features will be familiar to several generations of Cambridge medical men. Mr. Cope's portrait of Lord Alverstoke, Mr. Herkomer's portrait of Mr. Chamberlain, Mr. Bacon's portrait of Mr. 'T. P. O'Connor, Mr. Furse's portrait of Sir Francis Mowatt are all sound pieces of work and the same may be said of Mr. John Collier's portrait of Professor Ray Lankester, but in a portrait of Mr. H. T. Butlin this gifted artist hardly does himself justice. Mr. Draper's portrait of the nonagenarian Duchess of Abercorn is worth attention. It is a sympathetic representation of dignified old age, while the pains that he has expended upon the hands should be noted, pains which Mr. Sarjent appears to think waste of time.

Among many good landscapes the canvases of $\mathrm{Mr}$ Joseph Farquharson, Mr. Arnesby Brown, Mr. David Murray, and Mr. La Thangue are noticeable. Two of Mr. Farquharson's four canvases show that he can tear himself away from snow scenes, and it is to be hoped that he will not allow the public, who are so insistent upon an artist repeating himself, to confine him to perpetual midwinter Several terrible examples this year among the Royal Academicians of the result of the constant treatment of the same theme in the same way should prove a warning. Mr. David Murray continues to paint in Oonstable's country and it speaks much for his skill when we say that his rendering of Flatford, showing the present appearance of the scene of the master's famous picture, "The Hay Wain," is quite satisfactory. Two of Mr. La Thangue's pictures are Italian scenes and two are English, and all four are excellent, the work of a man who has seen often, and never without learning some lesson, the effects of light, shade, and atmosphere which be depicts.

Sir Lawrence Alma-Tadema sends only one small but characteristic study-some classical ladies looking from a marble building over a blue sea. Sir E. J. Poynter and Mr. Orchardson, who run him close in cultivated favour, send three pictures each, but nothing of the first importance. The President's picture in Gallery II., “The Nymph's Bathing Place," is certainly beautiful, but the lady's skin seems to have been painted more to fit the colour scheme 